\title{
Democracy and National Integration; Appraising the Challenges of Nigeria from 2003 To 2011
}

\author{
Ikyase Johnkennedy Tersoo ${ }^{1}$, Egberi Anthony Ejue ${ }^{2}$ \\ ${ }^{1}$ department Of Political Science Federal University Wukari, Wukari Nigeria \\ ${ }^{2}$ department Of Political Science Federal University Wukari. Wukari Nigeria
}

\begin{abstract}
The major aim of this paper is to examine the Nigerian democracy and national integration. The paper reviewed that one of the greatest challenges that the Nigerian nation faces today is that of disunity among its population which have culminated negatively to the task of national integration. The paper contend that the Nigerian way of practicing democracy has been characterized by poor and bad governance, corruption, electoral malpractices, political black mail etc have greatly impeded the process of national integration. Much of the setback to Nigerian national integration efforts is compounds by the way and manner the various political parties conduct and condone their actions towards the struggle for power. The paper recommend among other things that the consolidation of democracy could be best harnessed when there is reasonable understanding among federating unit without ethnic identify religious bigotry, nepotism, corruption, violence, bad governance and other factors that pose threats to political stability and national integration. The paper conclude that democratic principles of (popular sovereignty s, participation, constitution, among others) have not been allowed to take roots while the capacity of democratic institutions has remained weak.
\end{abstract}

Keywords: Democracy, National Integration, Challenges, Liberal, Nigeria.

\section{Introduction}

It has been observed that democracy as a system of government has a universal appeal. Nigeria as a nation has had several tastes of it but were all truncated by military intervention. Nigeria however was fully ushered into a democratic dispensation in May 1999; Nigeria paraded it as a scepter of progress, development and modern civilization with its tentacles of peace, unity and progress. Thus, there is no doubt that democracy is traceable to the ancient Greece specifically in the polis or city state of Athens. In ancient Greece, every adult male citizen participates in the process of reaching at decisions for the governance of the community. Agu, G. (2009). By implication, democracy in ancient Greece meant direct and active participation of the citizens in the affairs of polis or city state. As practiced in ancient Athens, Anifowose (2005) posits that, democracy was characterized by two distinguishing features, first, the supreme power was vested in the Ecclesial the assembly of all male citizens of which each was entitled to participate in discussion and voting. The second feature permitted freedom of speech and the third, it made all political offices open to all citizens who were chosen by lots. The emphasis here was that, checks and control were put to prevent individual or group from acquiring excessive power. This form of governance practice by the Greeks gives them a better understanding and integration among themselves.

However the Nigeria situation has presented itself in a different way. This is predicated on the fact, that since 2003 to 2011 the democratic dispensation has manifested traits of poor integrative mechanism based on conflicts and mutual suspicion that exist not only between the north and south but also within the religious angle. Infact, democratically speaking, the Nigerian state exist as divide between the north and south interms of power acquisition at the federal level based on the principles of rotational presidency" This no doubt explain the political topsy-turvy associated with the demise of Umaru Musa Yar Adua as the president of Nigeria in may 2010 vis-a-vis the heightened activities of Boko-Haram the Northern ethnic militia that favours the majority of islam in the north (Omodia 2012) The constitutional takeover of the presidential seat by Goodluk Jonathan from the south in 2011 to most northerners has been costly and damaging to national integration because of the anomic scenario in the north especially after the outcome of the 2011 presidential elections which witnessed mass killing of southerners in the north and the subsequent rejection of about 6696 batch B southern National youth service corps members from serving in some state in the northern part of the country (Daily Trust July 2012).

It is against this background that this paper seeks to unravel democracy and national integration in Nigeria with particular emphases on the challenges. The paper has been collapse in to seven sections. The first part presents the introduction. The second part examines the concepts of democracy and national integration. The third section examines the theoretical perspective. The fourth parts explore the nexus between democracy and national integration. The fifth sections expound democracy and the challenges of national integration. The 
six sections considered democracy and the holistic implication to national integration. The final section deals with conclusion and recommendations

\section{The Concept of Democracy}

Typical of all social science concepts, democracy cannot be boxed into a unilateral definition. However, there are several attempts in that light which if aggregated may offer a window into the meaning of democracy. In the words of Anifowose (2005) democracy is essentially a method of organizing society politically. He further adds that:

There are, it is suggested, five basic elements without which no community can call itself truly democratic these elements are equality, sovereignty of the people, and respect for human life the rule of law and liberty of individuals.

The author explains that democratic equality implies one man one vote irrespective of the differences in wealth, religion, intelligence etc. It also connotes the equal rights and opportunity of all citizens to hold political offices. Based on the elements of political equality of all is the principle of popular sovereignty the nation that ultimate political power or sovereignty rest with the mass of the people in practice popular sovereignty is express through representation and majority rule. It is through their representative that the people express their will.. In other words democratic regime should be based on the rule of law. A democratic regime should also respect certain basic freedoms from its citizens, these freedoms include among other things freedom of speech, freedom of the press, freedom of the conscience, and freedom of assembly (1999 Nigerian constitution as amended). This definition underlines the cardinal contents of liberal democracy which may however be faulted for its lack of emphasis on the role of political parties in the democratic process. This deficiency is remedied in the definition provided by Haruna, (2010) who notes that democracy entails meaningful and extensive competition among individuals and organized groups (especially political parties) either directly or indirectly for the major position of governmental power. In addition to popular participation in the electoral process and respect for the civil and political rights of the people it must be noted that the existence of numerous parties and conduct of periodic elections may not result in popular choice of leadership. Duruji, (2010) has provided what may be regarded as a summation of the varied definition of liberal democracy and a listing of its major elements. According to him liberal democracy in its contemporary form includes a cluster of rules and institutions permitting the selection of representative who alone can make political decisions. In more specific terms, he explains that:

The cluster includes elected government, free and fair elections in which every citizen's vote have an equal weight. A suffrage which embraces all citizens. Irrespective of distinctions of race, religion, class, sex and so on. Freedom of conscience information and expression on all public matters broadly to oppose their government and stand for office and associational autonomy. The rights to form independent associations including social movements interest groups and political parties.

However, the whole mark of democracy resides with the citizen's political investment, political participation and trust. It also connotes popular rule, individual's political life, equality among citizens and justice in the relations between the people and the government.

\section{The Concept of National Integration}

As a result of its multifarious usages, national integration as a concept does not lend itself to any universally accepted definition. This is why Stephnie (1976) describe it as an academic jargon. Ojo (2009) pointed out that integration as a concept is common to social science disciplines and means different things to different scholars. He identifies economic integration, socio-cultural integration as well as political or national integration. Coleman \& Roseburg jr (1964) define national integration as a broad subsuming process whose two dimentions are political integration and territorial integration while political integration has to do with progressive bridging of the elite mass gap on the vertical plane, while territorial integration refers to the progressive reduction of cultural and regional tension in the process of creating a homogeneous territorial political community. In the same vein Olawore \& Adisa (2008) defined national integration as the attempt at uniting or bringing together the hitherto multi-ethnic groups of people with diverse cultural, historical, language, religions and beliefs systems into one which would remove primordial and subordinate loyalties and sentiments to ethnic nationalities.

On a whole, national integration encapsulate the building of nation state out of disperate socio economic religious, ethnic and geographical elements which translate into diffuse and unorganized sentiments of nationalism into the spirit of citizenship through the creation of policy and programme that are in line with the citizenry. 


\section{Theoretical Perspective}

In this work we utilize the Integration theory" as the theoretical framework in analyzing the issues that are germaine to the understanding of this work. It is a theory propounded by Anital Etzoni in 1960s. He use differentiation models with the concept of differentiation according to him society in general changes as a result of integration. According to him, integration is simply the adaptive response of plural, small and medium size states to global challenges they could not face individually. He further opines that integration presupposes existence of some elements of pluralism which may be ethnic social-cultural economic, language or political by which each group may be marked to the point of engendering some measures of self-consciousness that can under the process of creating a sense of territorial neutrality. The territorial unit so created through integration process is to reduce tension in democratic society in order to bring out unity and homogeneity, reduction in political inequality among the major ethnic groups, with some inter-ethnic revelries.

This theory is vital in explaining democracy and national integration in that the fear of political domination has contributed to the lack of national consensus and integration. These in turn has lead to reactions and conception among the members of the political class and elites along ethnic and sometimes parochial lines. All these have the mobilization of all productive forces in the nation for the attainment of national goals for integration means while the problems of national integration can be much attributed to the nature, pattern and process of politicking. The Nigerian democracy is characterized by a great deal of anti- democratic practices. The constitution itself is not well formulated let alone its proper articulation. Elections are rigged in most pattern and shameful manner the political parties in the nation lack dynamism, dedication to national cause and most importantly they lack clear and distinct ideology. On the social aspect, poverty among the majority masses of the nation enough to foster disintegration. The problem of ethnicity, regionalism, tribalism, nepotism, and ethnics conflict has been a much serious to grapple with alongside religious intolerance among Nigerians. It is because of these that, this theory seeks to address the above issue in a pseudo democracy like ours.

\section{Democracy and Challenges of National Integration in Nigeria.}

When Nigeria became independent in 1960 the problem of national integration remained one of the greatest. Investigation shows that one of the disturbing problems before and immediately after independence was the issue of ethnic conflicts in Nigerian democracy and nation building. Thus, there are other factors that hinder true democracy and national integration in Nigeria factors like, political crisis, corruption tribalism, and insecurity among other ones will be discussed in the next segment of this chapter.

However, ethnicity, tribalism and corruption are the major impediment to national integration. Nigeria is a country of over two hundred and fifty ethnic groups with different backgrounds. The first republic operates a constructive regional differences and provided a strong institutional base for group sentiment and ethnics. The political arrangement was regionally based and local and ethnic issues became highly politicized. Each region was administered by political parties organized along ethnic lines that vowed to protect the people interest and had nothing to do with other regions in the country. This situation further entrenched ethnicity and led to regional and sub-regional agitations in the country. Hassan (2006:48). In May 1999, mark the return of democratic rule in Nigeria with a multi party system in operation, this development further fostered ethnic conflict across the country. Nigerian could no longer accommodate one another as sentiments which fuelled ethnic massacres and the rise of militant regional organizations became the new order. The rush to introduce sharia Islamic law is some states in the north despite the virulent protest by the Christians further fuelled the ethno-religions conflicts in that part of the country. The question is why did ethnic conflicts assume a more daring and destructive posture.

Analysts believe that the introduction of democratic rule in Nigeria acted like a pressure which enables the people to vent their pent-up anger and express their group interest and further demand for more political power and equitable distribution of natural resources. However, a true democracy is build up on farmers, justice and equity. Nigerian democracy to some extent was able to provide his people with fundamental human rights. Democracies in Nigeria context contributed gradually in the struggle for national integration and in turn also contributed to the disunity of Nigeria nation, on the bases of it features that guarantees individual citizens freedom and political participation.

Democracy and national integration as it implies are contested terrain in the context of polity in Nigeria or any system of government that strives to survive so far, the Nigeria federation has been played by instability of war and other numerous out breaks of ethnic violent despite the setback Nigerian has not disintegrated there have been vigorous efforts design institutions that can promote democracy and national integration. In the same vein, the colonial power that initially laid the foundation of the Nigeria state also worked against the formation of a common national identity this initial lack of consensus has resulted in the numerous political problems that have pitted one ethnic group against another. As such nation building in post-colonial Nigeria has became a deliberate effort to create and imagined political community that will foster peace and unity. Over the years, 
Nigerians have learned that peace and unity cannot be realized without proper political representation for all ethnic groups as well as the fair and equitable distribution of resources.

Considering the above there are studies restricted to the roles of democracy in national integration, in which cannot be de-emphasized but it is important to note that certain issues has milted against democracy in the quest for national integration which can be address Under the following factors has been associated with it which clash of political interest or differences, ethnic and religious differences, corruption, power shift and ethno-regional tensions among other related factors will be discuss.

Clash of political interests or differences= Since Nigeria returned to democratic practice in 1999 there has been a problem of political crisis almost every year election is been conducted. This crisis range from marginalization of groups, manipulation of votes or sometimes as a result imposition of candidates. These has impacted negatively of Nigeria democracy and the process of national integration. This can be seen in the 2011 persidential primaries of the the PDP . At the fore front of this campaign is Alhaji Adamu Ciroma. After a bitter campaign struggle Alhaji Atiku Abubakar emerged as the candidate of the North who was eventually defeated by Dr. Good Luck Jonathan in the PDP Primary election.

As it is often said in politics there is no permanent friend but interests, the north decided to support Muhammadu Buhari of the CPC who was the strongest Challenge to Good Luck Jonathan. There was serious mobilization for Muhamadu Buhari in the North-West and North-East zone. The mobilization was so intensive in the north that the average man on the street was made to believe that Buhari was going to have a knel slide victory. Most of the early return of the elections results were from the North-west and North-East which showed the CPC candidate to have a Clare lead. By the time the results from the other zones started coming in trend was dematically changed in favour of Good Luck Jonathan Ujo (2012:340). Supporters of the CPC interpreted this to be an outcome of rigging despite the fact that international and local observes confirmed that the election was free and fair and reflected the will of the majority of electorates. The buildup tension degenerated into violent explosion mainly in the North state of Katsina, Kano, Kaduna, Bauchi, Adamawa, Gombe and Taraba state protested burnt places of religions worship, public buildings and the houses of the politicians from the ruling PDP and religions leaders consider to be related to party targeted INEC buildings and its personnel including NYSC members servings as INEC ad-hoc staff and in Bauchi State ten of them were killed in gruesome manner (The Nation 21 April 2011).

\begin{tabular}{|c|c|c|c|}
\hline Date & Location & Principal Actors & Sources \\
\hline Feb 2003 & Obudu Cross River & $\begin{array}{l}\text { Inter-political, party conflicts between ANPP and PDP } \\
\text { over council elections }\end{array}$ & Varguard Feb 52003 \\
\hline Feb, 2003 & Jato-Aka Benue & $\begin{array}{l}\text { Politically motivated conflicts between supporters of } \\
\text { ANPP, UNPP and PDP }\end{array}$ & vanguard 29 feb 2003. \\
\hline May,12 2003 & Effurnum Delta & $\begin{array}{l}\text { Political crisis between PDP and AD supporters in } \\
\text { Effurnum LGA }\end{array}$ & Vanguard 15, may 2003 \\
\hline Feb 17, 2004 & Takum Taraba & $\begin{array}{l}\text { politically motivated Mayhem between PDP and NDP } \\
\text { over LG elections }\end{array}$ & Vanguard feb, 192004. \\
\hline March 17, 2004 & Kwande Benue & $\begin{array}{l}\text { A renewed violence between ANPP and UNPP in Adikpo } \\
\text { and Jato-Aka.this was belive to be an extention of the } \\
2003 \text { crisis }\end{array}$ & Vanguard 24, may 2004 \\
\hline Nov 102004 & 'Akwa Anambra & $\begin{array}{l}\text { Political crisis with hundreds of youth stormed the state } \\
\text { capital destroying government properties }\end{array}$ & This day, Nov 2004 \\
\hline \multicolumn{4}{|c|}{ 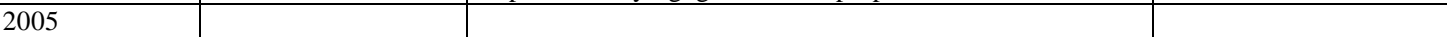 } \\
\hline \multicolumn{4}{|l|}{2008} \\
\hline 201023 oct & Akwa Anambra & $\begin{array}{l}\text { Internal crisis of the PDP about who become the next } \\
\text { governor of the state }\end{array}$ & Nation, 242010 \\
\hline April 2011 & Bauchi & $\begin{array}{l}\text { Politically motivated crisis by CPC over allege } \\
\text { manipulation of votes in favour of PDP }\end{array}$ & Nation 23 April 2011 \\
\hline 10 may 20011 & Akwa Ibom & Politically motivated between PDP \&CPC & Daily Trust 11 may 2011 \\
\hline
\end{tabular}

Source: Nigeria Newspapers 2011

It is the tradition of democracy that people be allowed to participate in the electoral process in an environment devoid of rancor. But as seen from the table above, elections in Nigeria over the years were not free and fair most of the protests were as a result of imposition of candidates of a particular political party on the people and marginalization of certain group of the people from certain political appointments. In some cases where a candidate of opposition wins in an election the result are always manipulated in favor of the ruling party. This is responsible for the widespread bickering and defections that followed the conduct of elections in the period under reviews. 
Ethnic and Religious Differences= Inter-and intra-ethnic rivalries and religios crisis constitute and potent challenges to democratic governance and national integration in Nigeria. Reading through the works of Best (2001), (Duru, Adewale 2009) and Duruji (2010:92) one sees these issue fairly handled and exhaustively treated. According to the Duruji (2010:92-93). The return of Nigeria to democracy in 1999 opened up the space for expression of suppress military rule. The expression of these demands have resulted in the emergence of ethno-nationalist insurgencies such as the movement for Emancipation of the Niger Delta (MEND) in the Niger Delta region the renewed demand for Biafra spearheaded by the movement for Actualization of sovereign state of Biafra (MASSIB) and the increasing notoriety of the Odua people congress (OPC) in the South-West. This has also resulted in incessant ethnic clashes in the middle Belt region and other parts of the country such as the ijaw Itshekiri ethnic clashes in 2009. There have also been frequent inter-regious clashes and sharia instigated riots in the Northern part of Nigeria as well as the emergence of the Boko Haram Islamic Jihadists with well known preferences in religious belief and social practices. Intra-ethnic cleavages as witnessed in the horrors of Ife/Modakeke and Aguleri/Umuleri fratricidal wars in the South-West and South-East regions respectively have also been the order of the day. These inter and intra-ethnic rivalries and religions crisis not only results in the loss of human and material resources that cannot be quantified in monetary terms which occasion untold economic hardship, they most fundamentally breed state of anarchy that threaten the unity and corporate existence of Nigerian state. Leaving those who act on behalf of the state with magnitude of national issues to contend with. For instance while the military in the Niger Delta took a heavy toll on the nation economy because of its independence on oil for foreign exchange earnings. The Boko Haram insurgency in the North has at the last count left over 16,000 police men, soldiers and civilians including politicians dead. (Nigerian crime News, March 13 2012).

Furthermore, given that these inter-religious and socio-cultural crisis occur outside of the confines of the law. They challenges and weaken democratic institutional mechanisms that are meant to check them and threaten the consolidation and survival of democratic governance and national integration Nigeria Duruji (2010).

Corruption= It is no longer news that Nigeria had acquired virtually all the features of a fails state, with corruption as the raison. Evens successive government have made promise to eradicate the menace but all eventually amounted to a mere grandstanding.

The looting of public funds by state governors and local government chairman is also at alarming rate. Examples include. The recovery of $\$ 364$ millions from the former plateau state governor Joshua Dariye which led to his impeachment. Corrupt practices performed by Governors chris Ngigi, Rachael Ladoja Ayo Fayose of Anambra, Oyo and Ekiti States respectively among others. At grass root level, corruption seemed to be more intensified. Chairman often divert monies allocated to various local government to facilitate the execution of projects into private use. There were series of allegations of corruption against the judiciary also it is important to note that there is no better test of the excellence of government than the efficiency of its judicial system Ujo. (2012). This is because the citizens feels secured with the assurances that he/she can rely on the certain, prompt and impartial administration of justices. Bearing this in mind, one is at a loose that to the role of the Nigerian judiciary in the Anambra state political crisis. A case in point was the purported removal of the former governor of the state Dr. Chris Ngige by an order of the federal high court Abuja presided over by Hon Justice Wilson Egbo-Egbo who later blamed it on a typographical error. This order and the judicial officer involved have been generally criticized. It was said.

His orders have aroused serious concern over the role of the judiciary in the fourth republic. The general impression is that of a defender of the establishment. But curiously though, he seems to be portraying the judicial institution as a partisan umpire (Admi, 2003 in salisu (2006).

Driving from the above manifestation of corruption. It is clear that the practice of democracy in Nigeria is in the miasma of political corruption and this has negative effect on national integration in a democratic system like. It is because of this that table below shows some corruption charges under Waziri's administration of EFCC an extract of the period under review 2003-2011.

\begin{tabular}{|l|l|l|}
\hline DEFENDANT & OFFICE HEAD & DATE CHARGES \\
\hline Babalola Borishade & Minster of Aviation (2005-2006) & July 2008 \\
\hline Femi Fani-Kayode & Minister of Aviation(2006-2007) & July 2008 \\
\hline Joshu Dariye & Governor plateau State (2003-2007 & July 2008 \\
\hline Boni Haruna & Governor, Adamawa State (1999-2007) & August 2008 \\
\hline Rashidi Olabode & Governor, Oyo State (2003-2007) 2008 \\
\hline Olabode George & Chairman, Nigerian ports Authority (1999-2003) & August 2008 \\
\hline Nicholas Ugbane & Chairman, Senator committee on power & May 2009 \\
\hline Ndudi Elumadu & Chairman, House of Representative, committee on power & May 2009 \\
\hline Igwe Pailinus & Chairman, House Of Representative Committee On Rural Development & May 2009 \\
\hline Jibo Mohammed & Deputy Chairman House of Representative committee on power & May 2009 \\
\hline Attahriu Bafarawa & Governor, Sokoto state (1999-2007) & December \\
\hline
\end{tabular}


Democracy and National Integration; Appraising the Challenges of Nigeria from 2003 To 2011

\begin{tabular}{|l|l|l|}
\hline Abdullahi Adamu & Governor, Nasarawa state (1999-2007) & March 2010 \\
\hline Nair El-Rufai & Minister of federal capital territory (2003-2007) & May 2010 \\
\hline Hassan Lawal & Minister of Works and Housing (2008-2010) & May 2010 \\
\hline Dimeji Bankole & Speaker of the house of the house of representative (2007-2011) & June 2011 \\
\hline Usman Nafada & Deputy speaker of the house of representative (2007-2011) & June 2011 \\
\hline
\end{tabular}

Source: EFCC Report, 2011

Power Shift and Ethno-Regional tension=The language of Nigeria politic often plays out in terms of ethnic regional domination is very wide. This is a language whose grammar is defined in two ways. The first is through control of political power and its instruments such as the armed force and the judicially. The second is through control of economic power and resources. Both affect the allocations of resources to group and individual. Both also contribute to the fear that is pervasive in Nigerian politics Nnoli, O. (1978).

Since the creation of Nigerian state the agitation for power shift and control has remain one among the major problem of democracy and national integration because of this the Nigerian fourth republic is not left out it is as a result of this that the federal character was introduce to controlled the rotation of power on regions in other to maintain peace and unity.

Considering the above, it is very sad to note that a lot of crisis exists in Nigerians federal system of government as a result of who and which region control political power at a particular time. Investigation show that in Nigerian fourth republic, the south West controlled political power starting from 1999 to 2007 where their return it to the north it is also very sad to know that the north could not continue with the process of governance as a result of the death of the former president Umaru Musa Yar-adua three year after occupying the seat of the presidency. After this, the power has again shifted to the south-south region if the country in 2011 there according to many scholars has brought a problem of Boko-Haram to Northern State.

In view of the above, the agitation of the power shift to different regions in Nigeria has pass a serious problem of natural unity to Nigeria democracy as many region wants to control political power at the same time.

Weak Democratic institution= The weakness of the democratic institution in Nigeria is another challenge to democratic governance and national integration. By democratic institution is refers to the executive judiciary, the legislature and electoral agency such as the independent national electoral commission (INEC). In principle, each of there institutions is constitutionally empowered to maintain a certain degree of independent and autonomy while serving as check on each other. In practice however, the tendency for the executive to dominate employing all manner of advantage on its side including the control of budgetary. Allocations remain a formidable reality. This dominance and over-bearing characteristics of the executive is located in the pattern and practice of dictatorship in Nigeria especially during the military era Bankole (2009) has asserted that decades of military dictatorship has had the effect of eroding constitutional federalism, the erosin of the culture of rule of law, the enthronement of a arbitrariness and impunity resulting in high levels of corruption. This legacy has fundamentally impacted on the power relations between the executive and other democratic institutions. The consequence of this has been the existence of subdued judiciary, weak oversight capacity of the legislature and the dumbness of the electoral bodies both at the federal and state levels.

Assessing the independence and autonomy of INEC and the judiciary in the fourth republic, Omodia (2009.38) has observed that events in this democratic dispensation have shown that the electoral body is not independent of the party in power. This according to him has been defined in relation to the manner in which the electoral body has conducted elections in the way that advantage the party in power while the judiciary has served as a tool for creating political controversy that under-mind the democratic process. Dunji (2010 102) has also observed that the judiciary has been unable to sustain the democratic process in Nigeria by finding to convict anybody through the judicial process for the several cases of aroson and killing that have characterized inter-and intral-ethnic clashes while the legislative institution has proven incapable of interfering decisively in management of ethno-religious and security crisis in Nigeria. According to Best (2001:75) the Nigerian police is an instrument of the state for the maintenance of law and other yet, it has repeatedly proved to be incompetent with respect to handing both simple and major internal conflicts, be they religious, ethnic, communal, etc while the state has failed to prosecute and punish people under the laws. These weaknesses of state institutions impact negatively on democratic practices and national integration and also threatens the consolidation of democratic governance in Nigeria. As Makinda (2004:20) has observed, democracy is only possible if the structures, processes and institutions through which the people's will is expected to be addressed accommodate their interest, values and aspirations. Constitutional democracy continues to falter not only because of the conduct of leaders but also because of inefficient, ineffective and deteriorating public institutions.

\section{Conclusion/ Recommendations}

In this work, conscious efforts have been made to appraise democracy and national integration in Nigeria. On this note it can be affirm that democracy finally made its triumphant entry into Nigeria in 1999 while the issue of national integration has long been pursued. The democratic principles of (popular sovereignty 
s, participation, constitution, among others) have not been allowed to take roots while the capacity of democratic institutions has remained weak. It is on this note that we offered the following recommendations. Firstly, the consolidation of democracy could be best harnessed when there is reasonable understanding among federating unit without ethnic identify religious bigotry, nepotism, corruption, violence, bad governance and other factors that pose threats to political stability and national integration. It is recommended that, integrative mechanism should be variously adopted and reviewed from time to time and synchronized to meet development and national needs of the country. Secondly, democracy generally is characterized by definite and defined principles. These include, adherence to the rule of law respect for fundamental human rights and the protection of life and property. For the prospect of democratic governance to be realized in order to enhance national integration these principle of democracy must not just be imbibed, they must be deepened.

Thirdly, the specification of constitution on the issue of federal character should be carefully defined in order to include all the region and ethnic groups. By doing this it will avoid the crisis that occur as a result of power sharing in the country. Fourthly, there is need for ideological mobilization i.e for mass education about democracy and the need for national integration in the country. This is by way of adoption of positive democratic culture or principles, people oriented constitutional reforms, good governance, media advocacy and political enlightenment programmes for general public. This can be achieved through value re-orientation. Institutions like national orientation Agency (NOA) should be strengthened in their efforts in order to achieve this. Finally, leadership and authority should be seen through the lenses of service stewardship transparency and accountability within the context of humility. Leadership and authority should not be seen as opportunities for stealing public funds.

\section{References}

[1]. Adejimbi, S. and Agbaje, A. (2006) Do votes Count: The travails of electoral politics in Nigeria. Dakar Council for the development of social science research in Africa-CODESRIA.

[2]. Adingwe, F. (1974), Essential of government for West Africa. Ibadan university press.

[3]. Agu, G. (2009) democracy human rights and rule of law in Nigeria. Makurdi destiny printing and publishing. Anifowose, R. (2005), elements of politics. Lagos Sam iroanusi publications.

[4]. Appadorai, A. (2004), the substance of politics. New Delhi oxford university press.

[5]. Bankole, D (2009) The role of the legislature in the consolidation of Democracy Nigreia. The Nation, June 29.

[6]. Best, S. (2001) "Religion and Religion conflicts in northern Nigeria "university of Jos journal of political science, 11(111), 63-81, December.

[7]. Durerger, M. (1976) federalism and national integration for development in Nigeria. Newyork John Wilwky.

[8]. Duruji, M. (2010) "Democracy and the challenges of ethno-nationalism in Nigeria fourth republic: integration international mechanism" journal of peace,conflict and development, 15, 92-106 March.

[9]. Edddy, A. (2006) political theory. New Delli .S. chad \& company Ltd.

[10]. Egwemi, V. (2008) Electoral fraud, legitimacy crisis and government of national unity option: focus on the 2007 general election Keffi oniwi publishing.

[11]. Eleazu, U. (1988) Nigeria the first 25 years. Nigeria Hermann educational books Nigeria Ltd.

[12]. Falola, T.(1991). History of Nigeria. Nigeria in the twentieth century, Books 3, Ikeja: Longman publishers.

[13]. Jega, A. (2006), democratization in Nigeria: problems and prospects, Claude Ake memorial lecture port-Harcourt centre for advance social science.

[14]. Mahajan, V. (2000), political theory New Delhi Chad \& company Ltd.

[15]. Makinda, S.M (2004) Between Authoritarianism and post Democracy: Agenda for Democracy in Africa. Africa Quarterly, 44 (1), 17-29 Nigerian Crime News, 31 May 2012.

[16]. Ndoma-Egba, V. (2000), forced unity: The national question" in okon Edet Uya, civil society and the consolidation of democracy in Nigeria, Calaba cats publication.

[17]. Nnoli, O. (1978) Ethnic politics in Nigeria, Enugu: fourth dimension publishers. A Multi- Ethnic Federal State. The Nigerian Experience. John Archers Ibadan.

[18]. Ojo,E (2009) Mechanism of National Integration in

[19]. Okoli, C. (2004) "National integration: The Nigerian experience" university of Uyo press.

[20]. Omodia, S. (2003), Elitist hedonism and democratic survival in Nigeria. The Nigeria academic forum 7 (3)

[21]. Omodia, S and Tinabu, B. (2009) Elections and democratic survival in the fourth republic of Nigeria. The journal of pan Africa studies.

[22]. Salui, H. (ed)(2006) democracy and development in Nigeria vol.1. Conceptual issues and democratic practice. Lagos: concept publications ltd.

[23]. Ujo, A. (2012) understanding the 2011 general elections in Nigeria, the beginning of a new era Kaduna Joyce graphic printers and publisher.

[24]. Weniner (1965). Political Integration and political development. London oxford press.

[25]. Yemi, A. (2009) justice sector return and human rights in Nigeria. Abuja. Centre for socio legal studies. 